\title{
Analysis of Dental Arch Dimensions in Three Colombian Ethnic Groups
}

\author{
Análisis de las Dimensiones del Arco Dental \\ en Tres Grupos Étnicos Colombianos
}

Padilla, M.*; Tello, L.*; Moreno, F.**; Osorio, J. C.**** \& Bedoya, A.*****

PADILLA, M.; TELLO, L.; MORENO, F.; OSORIO, J. C. \& BEDOYA, A. Analysis of dental arch dimensions in three colombian ethnic groups. Int. J. Morphol., 31(1):100-106, 2013.

SUMMARY: The purpose of this study was to compare dental arch transversal and anteroposterior dimensions in three ethnic groups from Colombia. A digital caliper was used to take 16 transversal and two sagittal measurements, 9 for the upper jaw and 9 for the lower jaw. The sagittal measure determining arch length was drawn from a mesial line traced from first right permanent molar to first left permanent molar, and a perpendicular line from the point of contact between central incisive teeth, both for the upper and lower jaw. The dimensions of upper dental arch in the three ethnic groups showed differences in intercanine distance, as well as between premolar and between molar teeth. The same differences were found for lower dental arches. The populations evaluated show distinctive characteristics in dental arch dimensions, thus the mestizo population had narrow arches while the natives had wide arches.

KEY WORDS: Dental arch; Arch length; Ethnic groups.

\section{INTRODUCTION}

The contact with European conquerors during the conquest and colonial periods determined the mixing of Indian communities with population groups from Europe and Africa. The genetic drift from those populations was not homogeneous, depending from different patterns of ethnic contribution and different mixing grades (Mesa et al., 2000). The native Indian from today's Colombian territory, suffered a continuous process of genetic mixing and nowadays there is only a small proportion of native isolated locations keeping their own traditions, culture and native language (Triana Antorveza, 1992). Hence, the contemporary Colombian population is a differential mixture of three kinds of ancestry: Amerindian, Afroamerican and European population. Each Colombian region has its own genetic background reflected by the predominance of certain phenotypes (Rondón et al., 2008).

Having a craniofacial complex influenced by genetic mixing, it is necessary to know how this affects the dental arch dimensions in the main Colombian ethniae. The knowledge of those changes has clinical implications for different medical, dental and anthropologic topics, and generates a change of dynamic functional paradigms regarding craniofacial structures, that in turn, generates changes in esthetic patterns as well. The new paradigm will be able to generate useful instruments to establish biotypes for our population and to assure that medical, orthopedic and orthodontic treatments will be related to real individual demands and possibilities in the context of ancestry.

Taking into account the environmental and genetic differences among the main three ethnic groups of the Colombian population and aiming to obtain further relevant knowledge about the Colombian inhabitants, to be dealt with in medical, dental anthropologic and forensic scenarios, the purpose of the present study is to establish whether there are significant differences in dental arch transversal and antero-posterior dimensions among the three ethnic groups more representative of Colombian population.

\footnotetext{
* DDS, Orthodontics and Maxillary Functional Orthopedics Specialist. Graduate Docent, Pediatric Dentistry and Maxillary Orthopedics, Valle University, and Graduate Docent, Orthodontics and Maxillary Orthopedics, Institución Universitaria Colegios de Colombia (UNICOC), Cali, Colombia.

** Biologist, MSc. Graduate Docent in Orthodontics and Maxillary Orthopedics, Institución Universitaria Colegios de Colombia (UNICOC), Cali, Colombia.

*** Dentistry Maxillary Orthopedics and Pediatric, Valle University, Cali, Colombia.

***** Dentistry. Research Group of Oral and Maxillofacial Surgery, Valle University, Cali, Colombia.
} 


\section{MATERIAL AND METHOD}

Sample. One hundred twenty-six plaster models from children 8 to 14 year old were obtained. The children belonged to three ethnic groups: 49 mestizo from Santiago de Cali (Valle), 40 Afro-Colombian from Villa Rica and Puerto Tejada (Cauca), and 37 South American Indian from Leticia (Amazonas). The inclusion criteria were: Prove of three generations of the same ethnia, healthy dental condition diagnosed, no previous orthopedic or orthodontic treatment, absence of congenital anomalies, presence of first molar permanent teeth in mouth, presence of two either temporal or permanent teeth, stable dental occlusion, Angle molar class I ; Overbite 30\%; 4mm maximum Overjet. Models from children with diagnostic of physical or mental systemic disease, or early dental exfoliation were excluded. All models were taken from alginate impressions Hydrogum ${ }^{\circledR}$ Zherman and prepared in dental plaster III Whipmix.

According to the Colombian normativity (Resolution 008430 from 1993) this research did not cause any risk for the participants or the community and it was approved by the Institutional Ethics Committee from the Faculty of Health, Valle University.

Measurements. It was used a calibrated Digital DC 1004 caliper with a scale from $0-150 \mathrm{~mm}$ (Stainless Hardened Discover $\left.{ }^{\circledR}\right)$, at a precision of $0.01 \mathrm{~mm}$. Each measurement was taken by the same previously calibrated investigator in three previously programmed sections. The total number of data was: 16 transversal dimensions and two sagittal, 9 for maxillary dental arch and 9 for mandibular dental arch, corresponding to: right canine vertex to left canine vertex; gingival vestibular margin of right canine to left canine, center of the occlusal groove from right first premolar to center of the occlusal groove of left first premolar, vestibular cusp of right first premolar to vestibular cusp of left first premolar; vestibular gingival margin from right first premolar to vestibular gingival margin of left first premolar, mesial first permanent molar fossa to mesial fossa of right first permanent to mesial fossa of the left first permanent molar; mesovestibular cusp of the right first permanent molar to mesovestibular cusp of left first permanent molar and vestibular gingival margin of right first permanent molar to vestibular gingival margin of the left first permanent molar. The sagittal arch length was taken from a line traced from right mesial first permanent molar to left first permanent molar and a perpendicular from the incisal contact point between central teeth, both for superior and lower dental arch.

Statistical analysis. The Kolmogorov-Smirnov test was used to determine normality of distribution for each variable.
Except for one parameter that required Kruskall-Wallis analysis, the other data were compared among ethnic groups by On way ANOVA and Tukey test for multiple average comparisons. All test were interpreted using a significance level $\mathrm{p}=0.05(\mathrm{a}=0.05)$. The statistical tests were performed using the software SPSS, version 15.

\section{RESULTS}

The statistical analysis of results indicated that for superior dental arch dimensions, the intercanine width (Cuspid right canine- left canine) presented significant differences, either taken from vertex ( $\mathrm{p}=0.007$ ) or from gingival vestibular groove $(p=0.001)$. The width between superior premolar $(\mathrm{PM})$ and molar $(\mathrm{M})$ was significantly different for the three ethnic groups either taken from cuspid vertex (PM p $=0.000$; $\mathrm{M} \mathrm{p}=0.000)$, or from gingival vestibular groove (PM $\mathrm{p}=$ $0.000 ; \mathrm{M} \mathrm{p}=0.000$ ) or from premolar and molar depth (PM $\mathrm{p}=0.000 ; \mathrm{M} \mathrm{p}=0.001)($ Table I).

The inferior dental arch dimensions presented the same pattern of ethnic differences for canine, premolar and molar widths (Table II).

The ANOVA for nine superior dental arch parameters, indicated significant differences between Afro and mestizo ethniae. The South American Indian presented significant difference with the other two groups only for arch length ( $\mathrm{p}$ 0.000) (Table III).

The ANOVA for inferior dental arch nine parameters indicated significant differences in the mestizo group for all dimensions but inferior arch length $(\mathrm{p}=0.43)$. For the afrodescent group the following differences were statistically significant: from gingival margin ( $\mathrm{p}=0.250)$, from depth of molar fossa $(\mathrm{p}=0.64)$ and premolar $(\mathrm{p}=0.26)$, and from molar cuspids ( $\mathrm{p}=0.37$ ). Additionally, this ethnic group did had significant differences in arch length $(\mathrm{p}=0.44)$. In the South American indian group, compared to the other two, there are no significant differences for any of the parameters measured (Table IV).

\section{DISCUSSION}

The comparison of superior arch intercanine width, indicates that the lowest distance was observed in the mes- 
Table I. Analysis of variance (ANOVA) for nine parameters for superior dental arch in three ethnic groups.

\begin{tabular}{|c|c|c|c|c|}
\hline Teeth & Parameter & Ethnic group & $\mathbf{n}$ & $\mathbf{P}$ \\
\hline \multirow{6}{*}{ Superior Canine } & \multirow{3}{*}{ Cuspid C-C_S } & Mestizo & 49 & \multirow{3}{*}{0.007} \\
\hline & & Afrocolombian & 40 & \\
\hline & & Indian & 37 & \\
\hline & \multirow{3}{*}{ Ging V margin C-C_S } & Mestizo & 49 & \multirow{3}{*}{0.001} \\
\hline & & Afrocolombian & 40 & \\
\hline & & Indian & 37 & \\
\hline \multirow{9}{*}{ Superior Premolar } & \multirow{3}{*}{ Ging V 1 $\mathrm{s}^{\mathrm{t}} \mathrm{Pm} \_\mathrm{S}$ margin } & Mestizo & 49 & \multirow{3}{*}{0.000} \\
\hline & & Afrocolombian & 40 & \\
\hline & & Indian & 37 & \\
\hline & \multirow{3}{*}{$\mathrm{V}$ cuspid $1 \mathrm{~s}^{\mathrm{t}} \mathrm{Pm} \_\mathrm{S}$} & Mestizo & 49 & \multirow{3}{*}{0.000} \\
\hline & & Afrocolombian & 40 & \\
\hline & & Indian & 37 & \\
\hline & \multirow{3}{*}{ Depth fossa $1^{\text {st }}$ Pm_S } & Mestizo & 49 & \multirow{3}{*}{0.000} \\
\hline & & Afrocolombian & 40 & \\
\hline & & Indian & 37 & \\
\hline \multirow{9}{*}{ Superior Molar } & \multirow{3}{*}{ Ging V 1 $\mathrm{s}^{\mathrm{t}} \mathrm{M} \_\mathrm{S}$ margin } & Mestizo & 49 & \multirow{3}{*}{0.000} \\
\hline & & Afrocolombian & 40 & \\
\hline & & Indian & 37 & \\
\hline & \multirow{3}{*}{ MV cuspid $1^{\text {st }} M_{-S}$} & Mestizo & 49 & \multirow{3}{*}{0.000} \\
\hline & & Afrocolombian & 40 & \\
\hline & & Indian & 37 & \\
\hline & \multirow{3}{*}{ Depth fossa $1^{\circ} \mathrm{M} \_\mathrm{S}$} & Mestizo & 49 & \multirow{3}{*}{0.001} \\
\hline & & Afrocolombian & 40 & \\
\hline & & Indian & 37 & \\
\hline \multirow{3}{*}{ Superior arch length } & & Mestizo & 49 & \multirow{3}{*}{0.000} \\
\hline & & Afrocolombian & 40 & \\
\hline & & Indian & 37 & \\
\hline
\end{tabular}

tizo group. Other published data, indicate that the lowest dimension for intercanine width has been found in Turks during early mixed dentition, class $\mathrm{I}(31.59 \mathrm{~mm})$ and in young permanent dentition population $(32.52 \mathrm{~mm}$ ) (Arslan et al., 2007). The intercanine width for Colombian mestizo population, 5 to 17 year old presenting normal occlusion normal was $33 \mathrm{~mm}$ (Alvaran et al., 2009). For Amazon Indians in early mixed dentition the intercanine width is 34.6 mmand $36.2 \mathrm{~mm}$ in late mixed dentition (Rivera et al., 2008).

There are also highly variable arch dimensions reported by researches that attribute this variability to dental size, bucco-lingual tipping and different response to functional masticatory loads, different masticatory activities and genetic factors (Eguchi et al., 2004; Corruccini, 1990).
In Norwegian children it was reported intercanine and intermolar maxilary and mandibular size higher but with a tendency to be reduced with time. The average transversal maxillary and mandibular width measured in children skulls was: intermolar: $46.11 \mathrm{~mm}$ and $43.57 \mathrm{~mm}$ respectively. For the intercanine width: $32.16 \mathrm{~mm}$ and $25.23 \mathrm{~mm}$ respectively maxillary and mandibular (Lindsten et al., 2002). The comparison of Norway data with those hereby reported indicates that afro-descendents present higher values for maxillary and mandibular transversal dimensions.

There is increasing evidence indicating that dental arch dimensions are determined by genetic and therefore ethnic factors (Lavelle, 1975; Goldstein \& Stanton, 1935; Foster et al., 1977). It is also documented that some 
Table II. Analysis of variance for nine parameters of inferior dental arch in three ethnic groups.

\begin{tabular}{|c|c|c|c|c|}
\hline Teeth & Parameter & Ethnic group & $\mathbf{n}$ & $\mathbf{P}$ \\
\hline \multirow{3}{*}{ Canine Inferior } & \multirow{3}{*}{ Cuspid C-C_I } & Mestizo & 49 & \multirow{3}{*}{0.002} \\
\hline & & Afrocolombian & 40 & \\
\hline & & Indian & 37 & \\
\hline \multirow{9}{*}{ Inferior Premolar } & \multirow{4}{*}{ Ging V $1 \mathrm{~s}^{\mathrm{t}} \mathrm{Pm} \_\mathrm{I}$ margin } & Mestizo & 49 & \multirow{3}{*}{0.003} \\
\hline & & Afrocolombian & 40 & \\
\hline & & Indian & 37 & \\
\hline & & Mestizo & 49 & \multirow{3}{*}{0.009} \\
\hline & \multirow[t]{2}{*}{ V cuspid $1 s^{t} P$ m_I } & Afrocolombian & 40 & \\
\hline & & Indian & 37 & \\
\hline & \multirow{3}{*}{ Depth fossa $1 \mathrm{~s}^{\mathrm{t}} \mathrm{Pm}_{-} \mathrm{I}$} & Mestizo & 49 & \multirow{3}{*}{0.055} \\
\hline & & Afrocolombian & 40 & \\
\hline & & Indian & 37 & \\
\hline \multirow{9}{*}{ Inferior Molar } & \multirow{3}{*}{ Ging V $1 s^{\mathrm{t}} \mathrm{M} \_\mathrm{I}$ margin } & Mestizo & 49 & \multirow{3}{*}{0.001} \\
\hline & & Afrocolombian & 40 & \\
\hline & & Indian & 37 & \\
\hline & \multirow{3}{*}{ MV cuspid $1 s^{t}$ M_I } & Mestizo & 49 & \multirow{3}{*}{0.001} \\
\hline & & Afrocolombian & 40 & \\
\hline & & Indian & 37 & \\
\hline & \multirow{3}{*}{ Depth fossa $1^{\circ}$ M_I } & Mestizo & 49 & \multirow{3}{*}{0.022} \\
\hline & & Afrocolombian & 40 & \\
\hline & & Indian & 37 & \\
\hline \multirow{3}{*}{ Mandibular arch length } & & Mestizo & 49 & \multirow{3}{*}{0.000} \\
\hline & & Afrocolombian & 40 & \\
\hline & & Indian & 37 & \\
\hline
\end{tabular}

populations, such as Australian aborigines, that consume fiber-rich and dry diets develop more muscle work demanding an additional functionality of the stomatognathic system, that is expressed in wider maxillary dental arches (Corruccini), as it is also observed in Amazon Colombian Indians, that present a good transversal development, harmonious occlusal relationships, low crowding index and very low incidence of open and anterior cross-bite (Bedoya et al., 2005).

There is also an observed evolutionary tendency to the reduction of arch dimensions, although body height is increased in contemporary human populations, which indicates that dental arches do not increase their dimensions proportionally to the general body size. Additionally it is likely that better care and nutrition do not increase the transversal arch length (Alvaran et al.; Bishara et al., 1995).

\section{CONCLUSIONS}

The populations evaluated in the present study present differential characteristics in dental arch dimensions. The mestizo population presents the lowest transversal arch dimension while the Amazon Indian presents the widest arch. The lowest sagittal length is registered in amazon indians while the highest sagittal length was present in afrodescendents. An important percentage of variability in these dimensions may be related to the ethnia, kind of food intake and geographic position. Therefore, the knowledge and study of these ethnic groups is relevant to provide adequate medical and orthodontic treatments taking into account specific normal characteristics. 
Table III. Analysis of variance for nine parameters of the superior dental arch in three ethnic groups.

\begin{tabular}{|c|c|c|c|c|}
\hline Teeth & Parameter & Ethnic group & n & $\mathbf{P}$ \\
\hline \multirow{6}{*}{ Superior Canine } & \multirow{3}{*}{ Cuspid C-C_S } & Mestizo & 49 & 0.128 \\
\hline & & Afrocolombian & 40 & 0.006 \\
\hline & & Indian & 37 & 0.471 \\
\hline & \multirow{3}{*}{ Ging V margin C-C_S } & Mestizo & 49 & 0.082 \\
\hline & & Afrocolombian & 40 & 0.000 \\
\hline & & Indian & 37 & 0.187 \\
\hline \multirow{9}{*}{ Superior Premolar } & \multirow{3}{*}{ Ging V 1 $\mathrm{s}^{\mathrm{t}} \mathrm{Pm} \_\mathrm{S}$ margin } & Mestizo & 49 & 0.000 \\
\hline & & Afrocolombian & 40 & 0.000 \\
\hline & & Indian & 37 & 0.995 \\
\hline & \multirow{3}{*}{$\mathrm{V}$ cuspid $1 \mathrm{~s}^{\mathrm{t}}{ }^{\mathrm{Pm}} \mathrm{S}$} & Mestizo & 49 & 0.001 \\
\hline & & Afrocolombian & 40 & 0.000 \\
\hline & & Indian & 37 & 0.894 \\
\hline & \multirow{3}{*}{ Depth fossa $1^{\text {st }} \mathrm{Pm} \_\mathrm{S}$} & Mestizo & 49 & 0.001 \\
\hline & & Afrocolombian & 40 & 0.000 \\
\hline & & Indian & 37 & 0.779 \\
\hline \multirow{9}{*}{ Superior Molar } & \multirow{3}{*}{ Ging V 1 $\mathrm{s}^{\mathrm{t}} \mathrm{M} \_\mathrm{S}$ margin } & Mestizo & 49 & 0.004 \\
\hline & & Afrocolombian & 40 & 0.001 \\
\hline & & Indian & 37 & 0.819 \\
\hline & \multirow{3}{*}{ MV cuspid $1^{\text {st }} M_{-S}$} & Mestizo & 49 & 0.001 \\
\hline & & Afrocolombian & 40 & 0.001 \\
\hline & & Indian & 37 & 0.992 \\
\hline & \multirow{3}{*}{ Depth fossa $1^{\circ} \mathrm{M} \_\mathrm{S}$} & Mestizo & 49 & 0.001 \\
\hline & & Afrocolombian & 40 & 0.028 \\
\hline & & Indian & 37 & 0.554 \\
\hline \multirow{3}{*}{ Superior arch length } & & Mestizo & 49 & 0.003 \\
\hline & & Afrocolombian & 40 & 0.104 \\
\hline & & Indian & 37 & 0.000 \\
\hline
\end{tabular}

PADilla, M.; TEllo, L.; MORENO, F.; OSORIO, J. C. \& BEDOYA, A. Análisis de las dimensiones del arco dental en tres grupos étnicos colombianos. Int. J. Morphol., 31(1):100-106, 2013.

RESUMEN: El propósito de éste estudio fue comparar las dimensiones transversal y anteroposterior del arco dental en tres grupos étnicos de Colombia. Se utilizó un calibrador digital para tomar 16 medidas transversales y dos sagitales, 9 maxilares y 9 mandibulares. La medida sagital para determinar la longitud del arco se elaboró a partir de una línea trazada desde mesial primera molar derecho permanente al primer molar izquierdo permanente, y una línea perpendicular desde el punto de contacto entre los incisivos centrales, tanto para el maxilar y mandíbula. Las dimensiones del arco dental maxilar en los tres grupos étnicos mostraron diferencias en la distancia intercanina, así como entre premolares y molares. Las mismas diferencias se encontraron en la mandíbula. Las poblaciones evaluadas presentan características distintivas en las dimensiones del arco dental, por lo que la población mestiza tuvo arcos estrechos, mientras que los nativos tuvieron arcos anchos.

PALABRAS CLAVE: Arco dental; Longitud del arco; Grupos étnicos. 
PADIlla, M.; TELLO, L.; MORENO, F.; OSORIO, J. C. \& BEDOYA, A. Analysis of dental arch dimensions in three colombian ethnic groups. Int. J. Morphol., 31(1):100-106, 2013.

Table IV. Analysis of variance for nine parameters of the inferior dental arch in three ethnic groups.

\begin{tabular}{|c|c|c|c|c|}
\hline Teeth & Parameter & Ethnic group & $\mathbf{n}$ & $\mathbf{P}$ \\
\hline \multirow{3}{*}{ Canine Inferior } & \multirow{3}{*}{ Cuspid C-C_I } & Mestizo & 49 & 0.090 \\
\hline & & Afrocolombian & 40 & 0.002 \\
\hline & & Indian & 37 & 0.346 \\
\hline \multirow{9}{*}{ Inferior Premolar } & \multirow{4}{*}{ Ging V 1s ${ }^{\mathrm{t}} \mathrm{Pm} \_\mathrm{I}$ margin } & Mestizo & 49 & 0.003 \\
\hline & & Afrocolombian & 40 & 0.044 \\
\hline & & Indian & 37 & 0.712 \\
\hline & & Mestizo & 49 & 0.017 \\
\hline & \multirow[t]{2}{*}{ V cuspid $1 \mathrm{~s}^{\mathrm{t}} \mathrm{Pm} \_\mathrm{I}$} & Afrocolombian & 40 & 0.033 \\
\hline & & Indian & 37 & 0.984 \\
\hline & \multirow{3}{*}{ Depth fossa $1 \mathrm{~s}^{\mathrm{t}} \mathrm{Pm}_{-} \mathrm{I}$} & Mestizo & 49 & 0.051 \\
\hline & & Afrocolombian & 40 & 0.262 \\
\hline & & Indian & 37 & 0.760 \\
\hline \multirow{9}{*}{ Inferior Molar } & \multirow{3}{*}{ Ging V 1 ${ }^{\mathrm{t}}{ }^{\mathrm{t}} \mathrm{M} \_$I margin } & Mestizo & 49 & 0.001 \\
\hline & & Afrocolombian & 40 & 0.250 \\
\hline & & Indian & 37 & 0.114 \\
\hline & \multirow{3}{*}{ MV cuspid $1 \mathrm{~s}^{\mathrm{t}}$ M_I } & Mestizo & 49 & 0.001 \\
\hline & & Afrocolombian & 40 & 0.366 \\
\hline & & Indian & 37 & 0.057 \\
\hline & \multirow{3}{*}{ Depth fossa $1^{\circ}$ M_I } & Mestizo & 49 & 0.019 \\
\hline & & Afrocolombian & 40 & 0.639 \\
\hline & & Indian & 37 & 0.670 \\
\hline \multirow{3}{*}{ Mandibular arch length } & & Mestizo & 49 & 0.429 \\
\hline & & Afrocolombian & 40 & 0.438 \\
\hline & & Indian & 37 & 0.459 \\
\hline
\end{tabular}

\section{REFERENCES}

Alvaran, N.; Roldan, S. I. \& Buschang, P. H. Maxillary and mandibular arch widths of Colombians. Am. J. Orthod. Dentofacial Orthop., 135(5):649-56, 2009.

Arslan, S. G.; Kama, J. D.; Sahin, S. \& Hamamci, O.Longitudinal changes in dental arches from mixed to permanent dentition in a Turkish population. Am. J. Orthod. Dentofacial Orthop., 132(5):576.e15-21, 2007.

Bedoya, A.; Rivera, S. \& Triana, F. Occlusion analysis of a native school children population in Amazonas. Int. J. Jaw Func. Orthop., 1:525-42, 2005.

Bishara, S. E.; Khadivi, P. \& Jakobsen, J. R. Changes in tooth sizearch length relationships from the deciduous to the permanent dentition: a longitudinal study. Am. J. Orthod. Dentofacial Orthop., 108(6):607-13, 1995.

Corruccini, R. S. Australian aboriginal tooth succession, interproximal attrition, and Begg's theory. Am. J. Orthod. Dentofacial Orthop., 97(4):349-57, 1990.

Eguchi, S.; Townsend, G. C.; Richards, L. C.; Hughes, T. \& Kasai, $\mathrm{K}$. Genetic contribution to dental arch size variation in Australian twins. Arch. Oral Biol., 49(12):1015-24, 2004.

Foster, T. D.; Grundy, M. C. \& Lavelle, C. L. A longitudinal study of dental arch growth. Am. J. Orthod., 72(3):309-14, 1977.

Goldstein, M. S. \& Stanton, F. L. Changes in Dimension and Form of the Dental Arches With Age. Int. J. Orthod. Dent. Child., 21:357, 1935.

Lavelle, C. L. The shape of the dental arch. Am. J. Orthod., 67(2):176-84, 1975.

Lindsten, R.; Ogaard, B.; Larsson, E. \& Bjerklin, K. Transverse dental and dental arch depth dimensions in the mixed dentition 
PADILlA, M.; TELLO, L.; MORENO, F.; OSORIO, J. C. \& BEDOYA, A. Analysis of dental arch dimensions in three colombian ethnic groups. Int. J. Morphol., 31(1):100-106, 2013.

in a skeletal sample from the 14th to the 19th century and Norwegian children and Norwegian Sami children of today. Angle Orthod., 72(5):439-48, 2002.

Mesa, N. R.; Mondragón, M. C.; Soto, I. D.; Parra, M. V.; Duque, C.; Ortíz-Barrientos, D.; et al. Autosomal, mtDNA, and Ychromosome diversity in Amerinds: pre- and post-Columbian patterns of gene flow in South America. Am. J. Hum. Genet., 67(5):1277-86, 2000.

Rivera, S.; Triana, F.; Soto, L. \& Bedoya, A. Forma y tamaño de los arcos dentales en una población escolar de indígenas amazónicos. Colomb. Med., 39(1):51-6, 2008.

Rondón, F.; Osorio, J. C.; Peña, A. V.; Garcés, H. A. \& Barreto, G. Diversidad genética en poblaciones humanas de dos regiones colombianas. Colomb. Med., 39(2):52-60, 2008.

Triana Antorveza, A. La colonización española en el Tolima siglos XVI y XVII. Bogotá, Cuadernos del Jagua, 1992.

\author{
Dirección para correspondencia: \\ Dr. Antonio Bedoya \\ Postgrado de Ortodoncia y Ortopedia Maxilar \\ Institución Universitaria Colegios de Colombia (UNICOC) \\ Cali
}

COLOMBIA

Email: julio.osorio@correounivalle.edu.co

Received: 27-04-2012

Accepted: 10-09-2012 